DOI:10.17951/h.2019.53.3.73-83

\begin{tabular}{lcc}
\hline \multicolumn{1}{c}{ A N N A L E S } \\
UNIVERSITATIS MARIAE CURIE-SKŁODOWSKA \\
LUBLIN - POLONIA \\
VOL. LIII, 3 & SECTIOH H \\
\hline
\end{tabular}

\title{
JOLANTA SZOŁNO-KOGUC
}

jszolno@hektor.umcs.lublin.pl

Maria Curie-Skłodowska University in Lublin, Faculty of Economics

5 Marii Curie-Skłodowskiej Sq., 20-031 Lublin, Poland

ORCID ID: http://orcid.org/0000-0003-4745-0001

\section{NATALIA OŁÓWKO}

natalia.olowko@gmail.com

Maria Curie-Skłodowska University in Lublin, Faculty of Economics

5 Marii Curie-Skłodowskiej Sq., 20-031 Lublin, Poland

No ORCID ID

\section{The phenomenon of tax avoidance - the essence, causes and measures (clauses) of prevention in the EU}

Keywords: taxation; tax avoidance; BEPS; Anti-Tax Avoidance Directive

JEL: H21; H25; M48

How to quote this paper: Szołno-Koguc, J., \& Ołówko, N. (2019). The phenomenon of tax avoidance - the essence, causes and measures (clauses) of prevention in the EU. Annales Universitatis Mariae Curie-Skłodowska, sectio H-Oeconomia, Vol. 53, No. 3.

\footnotetext{
Abstract

The problem of tax avoidance in the European Union (EU) has existed since the beginning of the EU internal market and is an important aspect at both the national and international levels. Among the most important reasons for this phenomenon are the inconsistent regulations and solutions applied in the tax systems of individual countries, the diverse and complicated nature of financial instruments and structures, the insufficient cooperation of tax administrations in EU countries or harmful tax competition. This state of affairs causes negative consequences for the budgets of individual countries and discriminates against honest taxpayers, because tax profits derived from tax evasion are invested in a competitive struggle against companies that reliably settle accounts with the tax authorities. The construction of an efficient and effective, yet fully fair
} 
tax system in the EU is intended to eliminate or significantly reduce the problem of tax avoidance. This is achieved by the measures currently underway (e.g. the introduction of a directive against tax avoidance or the elaboration by the Organisation for Economic Co-operation and Development (OECD) regarding the recommendations for local administrations in the field of national tax regulations). This article aims to highlight the importance of the tax avoidance problem and to present selected actions to solve it at both the national and EU levels. The structure of the study has been subordinated to the above, as along with the applied research method, including the analytical and conceptual approach.

\section{Introduction}

The problem of tax avoidance in the European Union (EU) has existed since the beginning of the EU internal market and is an important aspect at both the national and international levels. Among the most important reasons for this phenomenon are the inconsistent regulations and solutions applied in the tax systems of individual countries, the diverse and complicated nature of financial instruments and structures, the insufficient cooperation of tax administrations in EU countries or harmful tax competition. This state of affairs causes negative consequences for the budgets of individual countries and discriminates against honest taxpayers, because tax profits derived from tax evasion are invested in a competitive struggle against companies that reliably settle accounts with the tax authorities. The construction of an efficient and effective, yet fully fair, tax system in the EU is intended to eliminate or significantly reduce the problem of tax avoidance. This is achieved by the measures currently underway (e.g. the introduction of a directive against tax avoidance or the elaboration by the Organisation for Economic Co-operation and Development (OECD) regarding the recommendations for local administrations in the field of national tax regulations). This article aims to highlight the importance of the tax avoidance problem and to present selected actions to solve it at both the national and EU levels. The structure of the study has been subordinated to the above, as along with the applied research method, including the analytical and conceptual approach.

\section{Definition of "tax avoidance" and "aggressive tax planning"}

Tax avoidance is a natural effect of the public authorities' interference in property relations. This activity is almost certainly as old as the tax institution itself. From the very beginning, market participants sought ways to minimise tax liabilities and public authorities tried to limit this practice. Tax avoidance is a global problem and international steps are needed to overcome it. This is why many activities are undertaken, e.g. by OECD or European Commission (EC) authorities. These actions are primarily aimed at improving instruments to combat tax fraud and implementing new tools to achieve this goal. Considering the importance of this phenomenon, the focus should be on the definition of the key concept in the context of the discussed topic. 
Attempts to define the concept of tax avoidance today can cause many difficulties. This is a multifaceted notion that should be examined not only from the legal, but also from the economic, social and even philosophical perspective. From a legal point of view, the phenomenon of tax avoidance is closely related to a particular tax system, because its legality or illegality depends on the legal norms issued by an individual state authority. Since different legal systems are in force in individual countries, it is impossible to create a general definition of tax avoidance based on the provisions of tax law. In Poland, in the Tax Ordinance Act (Polish Tax Ordinance Act of 29 August 1997, Art. 119a § 1), tax avoidance is described as an act performed primarily to obtain a tax advantage, which means other motives are irrelevant. Moreover, the activity is contrary to the essence and purpose of the tax act.

The definition by HM Revenue and Customs can also be cited as an example. According to this organisation, tax avoidance is an activity that

(...) involves bending the rules of the tax system to gain a tax advantage that Parliament never intended. It often involves contrived, artificial transactions that serve little or no purpose other than to produce this advantage. It involves operating within the letter - but not the spirit - of the law. Most tax avoidance schemes simply do not work, and those who engage in it can find they pay more than the tax they attempted to save once HMRC has successfully challenged them (HM Treasury, HM Revenue \& Customs, 2015, p. 5).

Even the OECD states "avoidance" in the glossary as a term difficult to define, equally stating that it is "used to describe the arrangement of a taxpayer's affairs that is intended to reduce his tax liability and that although the arrangement could be strictly legal it is usually in contradiction with the intent of the law it purports to follow" (OECD, 2007). Consequently, the most characteristic aspects of tax avoidance are the usage of legal methods to fulfil the purpose, i.e. minimising taxes and contradicting the purpose and essence of the tax act.

Regarding tax planning, based on the OECD's glossary (OECD, 2007), it is described as an arrangement of a person's business and/or private affairs to minimise tax liability. However, the widely analysed phenomenon is currently aggressive tax planning. As has been defined by the EC in its 2012 Recommendation, aggressive tax planning consists of taking advantage of technicalities in a tax system or mismatches between two or more tax systems for the purpose of reducing tax liability. In effect, aggressive tax planning abuses the differences in individual tax systems. Holding companies or conduit companies may be used by international firms to extract a country tax treaty network or low tax jurisdictions to reduce their tax liability (e.g. redirecting the income obtained in one country or taking advantage of exemptions or deductions assigned to holding structures) (Mosquera, Akunobera, Mazz, Quiñones Cruz, Schoueri, Roeleveld, West, Pistone, \& Zimmer, 2018, p. 150). Furthermore, on 21 June 2017, the EC published a proposal for amending the directive on administrative cooperation in the field of taxation (Directive 2011/16/ 
EU) and listed "hallmarks" (strong indicators of tax avoidance or abuse) in an annex to the proposal. For instance, as hallmarks were specified, arrangements were made concerning the following: the use of losses, the conversion of income into a lower-taxed category of revenue, and deductible cross-border payments that take advantage of a preferential tax regime at the recipient level where the recipient is a resident in a jurisdiction that imposes corporation tax at less than half the average rate in the EU or in a jurisdiction included on the EU tax haven blacklist.

\section{The causes of tax avoidance}

Regarding the reasons for the occurrence of the tax avoidance phenomenon, they are based on striving to offset or completely reduce the tax burden by natural persons and legal persons. This is caused by the use of too high tax rates by individual countries. Thus, taxpayers are looking for the possibility of minimising the depletion of their income because of taxes. Today, the largest income is generated by economic entities. Therefore, one important reason for tax avoidance is the negative impact of taxes on the economy. The negative aspect of the tax law impact on the economy is mainly due to the increase in the tax burden. This leads to the limitation of the development of economic entities, because the payment of an increasingly higher tax reduces their monetary resources. Due to the lack of sufficient financial resources, the entrepreneur can not only invest, but also often loses current financial liquidity. The logical consequence of this is the loss of competitiveness on the market, which in effect compels a specific economic entity to withdraw from business. Adam Smith, an eighteenth-century Scottish thinker and economist, claimed that "too high tax burden drains the farm, i.e. dries out the source that lives off" (Smith, 1954, pp. 584-587). A well-known American specialist in economics, chief adviser in the economic policy of President Ronald Reagan, Arthur B. Laffer, came to similar conclusions. This economist became famous primarily for the concept of the so-called "optimal tax rate" (Laffer, 2004). This theory assumes that there is a relationship between the amount of the tax rate and the amount of tax revenues to the state budget. Laffer believed that the increase in the tax rate triggers two opposite effects. The first of these is to increase the share of the state budget in the income of business entities, and the second is to reduce the taxpayers' income declared for taxation. This is because, as the tax rate increases, the economic motivation to take up work and business decreases. However, the tendency of business entities to hide their income and enter the "grey zone" increases. This is the reason for the increase in unemployment and the deterioration of investment conditions. Therefore, when imposing taxes, the state should strive to obtain an optimal tax rate. It is determined by the "saturation point" in which tax receipts reach their amplitude. This point, above which the amount of tax revenue begins to decrease, determines the Laffer curve. However, this phenomenon is purely theoretical, and in practice, both the determination of this point and the remaining course of the curve are unknown. It 
is not enough to set the appropriate tax rates to determine it. What is also needed here is a thorough economic analysis of the market.

The reasons for international tax avoidance are also mentioned in the multitude, intricacy and structural complexity of tax optimisation instruments. However, it should be remembered that the tax strategies of international holdings are constructed on the basis of several tax jurisdictions simultaneously: domestic legislation, where holding structures operate (there may be several to several dozen - depending on the holding structure), European tax law and international tax law. One should be aware of the breadth of the entire tax jurisdiction on the grounds of which the international holding is building its strategy. The international tax law itself means hundreds of international agreements that are effectively used by holding companies to avoid taxation. The scope of this problem is usually beyond the possibilities of tax control. The essence of international tax avoidance is complicated by unfair tax competition between member states. This is a phenomenon that has permanently entered the economic realities of the EU. Member States, which should act jointly and severally against international tax avoidance (or at least not disturb each other), have begun to compete with each other in tax solutions dedicated to international holding companies. By proposing the most beneficial solutions, countries want to encourage international holding companies to locate their activities and pay taxes in their territory, even if taxes are much lower than expected, but still satisfying. Member States are aware that they will not stop the trend of optimising taxation; therefore, they have begun promoting their own tax systems as the most beneficial, and certainly more beneficial than the solutions proposed by neighbouring Member States. Such a policy of unfair tax competition has become a fact and debunks the idea of common tax compliance. A classic example of this is the LuxLeaks scandal.

\section{The scale of the phenomenon in EU countries}

International tax avoidance under the corporate income tax (CIT) has become a global trend, which has now reached such a level that it truly threatens not only budgetary interests, but also their security. This is reflected in the losses due to international avoidance of CIT in Poland, which have reached PLN 46 billion annually (Gajewski, 2015, pp. 9-21). The scale of the phenomenon allows us to state clearly that the problem has been growing for a long time and it can be assumed that the relevant services either underestimated it, did not see it, or did not have the idea of effectively counteracting this phenomenon. In addition, the scale of the problem was proved by successive scandals: Panama Papers, Offshore Leaks, Swiss Leaks or the aforementioned LuxLeaks. This resulted in a clear disclosure of the weaknesses of the control system regarding the issue of transferring profits between individual companies within the holding.

There are significant reasons for difficulties in estimating the amount of tax avoidance in an economy. The first and the most obvious is that there is no strict 
legal definition of what tax avoidance is and, therefore, any estimate will always be subject to dispute by those who simply disagree on definitional issues as to what is and what is not tax avoidance. Second, a great deal of tax avoidance activity involves cross-border transactions. It is, therefore, notoriously difficult to determine where tax avoidance might take place, even if it is known that it is occurring. Third, even official estimates - such as those by the US Internal Revenue Service published in January 2012, tend to ignore the issue. The word "avoidance" is not mentioned in their report (Internal Revenue Service, 2012). The Swedish National Tax Agency has not avoided this issue, but it is all too aware of the problems of preparing any estimates, stating in its 2008 report The Tax Gap Map for Sweden (Swedish National Tax Agency, 2008): "The uncertainty is considered greatest with regard to the tax gap with international connections and the tax gap for large companies, where there is a not insignificant amount of tax avoidance. In addition to the difficulty of calculating the size of the gap that exists, it is in many respects difficult to decide what a tax gap is". This leaves a very limited number of reports to look at and make any suggestions regarding the scope of tax avoidance in the EU.

There are many different estimates and reports on the scale of tax avoidance in general and for specific companies. They were developed by tax administrations, non-governmental organisations, academia and the press. However, there are no reliable figures on the scale of tax avoidance by enterprises, although it is generally recognised that these are significant values (some of the highest estimates indicate an amount of EUR 860 billion per year due to tax evasion ${ }^{1}$ and 150 billion per year due to tax avoidance) (Murphy, 2012, p. 2).

\section{The effects of tax avoidance}

The legitimate activities of the taxpayer, which are not aimed at achieving any economic result, and their only goal is to achieve tax benefits, are doubtful from the point of view of tax law. Doubts of a moral nature arise because the legislator, creating tax regulations, assumes the rationality of taxpayers' actions in the economic sphere. Therefore, if the tax goal is the only determinant of the taxpayer's actions, then it is possible to discuss the fictitious matching of specific situations to the most tax-favourable situation for the taxpayer. Behaviours contrary to the assumptions adopted by the tax legislator result in a higher taxation of those taxpayers who act in a rational manner in the sphere of social relations. The taxpayer manoeuvring with artificial forms of business transactions achieves undeserved benefits in relation to taxpayers who act in a manner adequate to the legislator's assumptions. The general

\footnotetext{
1 Due to the OECD glossary (OECD, 2007): "A term that is difficult to define but which is generally used to mean illegal arrangements where liability to tax is hidden or ignored, i.e. the taxpayer pays less tax than he is legally obligated to pay by hiding income or information from the tax authorities".
} 
assumption adopted in the creation of tax law is that the taxpayer operates in a manner typical for a given type of social and especially economic relations. The operation of abstract and general standards makes sense only with such assumptions. Tax law institutions are designed for taxpayers acting in this way (Kurzac, 2017, pp. 14-15).

The negative effects of international tax avoidance are not the same for each Member State. These effects depend on several aspects, including on the level of systemic security against tax optimisation instruments, the level of awareness and training of the tax office, which performs control activities, and finally whether the state has a long-term strategy dedicated to honest international holding companies (holding tax law) and aggressively holding companies optimising taxation. The consequences of international tax avoidance have a special impact on the fiscal condition of Poland.

As part of international tax avoidance, one should notice another very dangerous phenomenon, the so-called spoiling a good taxpayer, which can be observed especially in Poland. The lack of an effective strategy against international tax avoidance results in holding companies that engage in this practice using their tax savings to fight against competition (e.g. through the use of dumped prices). Accordingly, holding companies that do not use aggressive tax optimisation are no longer competitive. The long-term presence of such a situation creates a difficult dilemma: either lose the fight against aggressive taxation companies, which will result in the liquidation of activities, or also start unfairly optimising taxation. Holding companies are aware that they cannot count on a state that is ineffective in combating international tax avoidance. Simultaneously, they realise that if the state is ineffective in relation to holdings that use strictly defined constructions that aggressively optimise taxation, it will also be ineffective in relation to them if they adopt a similar tactic. This is undoubtedly a very dangerous phenomenon for the state, which somehow encourages taxpayers to use all, even the non-allowed methods of tax optimisation. The conclusion is also that the incapability of the state and the lack of systemic solutions in combating international tax avoidance results in an increasing number of dishonest taxpayers.

\section{Ways to combat tax avoidance}

Such a significant scale of the phenomenon and the serious negative effects mentioned in the previous section of the article indicate the legitimacy of taking all measures aimed at limiting the scale of tax avoidance in EU countries.

The first step was to be the Common Consolidated Corporate Tax Base (CCCTB) directive. Thanks to the CCCTB, cross-border companies were to follow only one, single EU system for computing their taxable income rather than many different national rulebooks. The proposed draft directive was also intended to regulate the taxation of international holdings and prevent tax avoidance, but it proved to be a solution with numerous drawbacks that would foster aggressive tax optimisation. 
It is also noteworthy that other concepts that were intended to harmonise holding tax law and which would counteract international tax avoidance have not been successful:

- European Union Corporate Income Tax (EU-CIT);

- Compulsory Harmonised Single Tax Base (CHSTB);

- Home State Taxation (HST);

- spontaneous harmonisation of Member States;

- harmonisation through the "back door" of the CJEU (harmonisation as a result of reactions to judgments of the Court of Justice of the EU);

- harmonisation limited to selected legal issues and aimed at solving specific individual problems through the so-called targeted measures).

They had numerous defects and imperfections, and above all they were not of a comprehensive nature. Consequently, the EC decided that the CCCTB concept had the highest chance of success, which later turned out to be a mistake (Gajewski, 2015, pp. 9-21).

In December 2012, the EC published a final report on actions to strengthen the fight against avoidance and evasion of taxes: An Action Plan to strengthen the fight against tax fraud and tax evasion (Communication from the Commission to the European Parliament and the Council, 2012). This plan presents strictly defined actions that should be introduced in waves. The plan brings a new value to the international discussion regarding taxation and tries to support the group of G20 and G8 countries in joint work regarding tax issues. This was supported by the G20 Leaders' Declaration of 19 June 2012 in Los Cabos: "We reiterate the need to prevent base erosion and profit shifting and we will follow with attention the on-going work of the OECD in this area" (Pasternak-Malicka, 2013, p. 60).

The fruit of cooperation was the report Action Plan on Base Erosion and Profit Shifting (Action Plan on BEPS) (OECD, 2013) published in July 2013 by the OECD and the G20 Member States. The aim of the plan is to coordinate the actions of many countries against tax avoidance by enterprises with a cross-border or global structure.

The sealing of the tax system is to be served by specific activities in 15 highlighted areas, including:

- creating instruments to eliminate or neutralise the effects of hybrid structures;

- improving transfer pricing rules and addressing areas that generate undesirable effects;

- updating income taxation solutions, in particular in the field of digital products and services;

- introduction of tools allowing effective counteracting tax avoidance;

- introduction of provisions on the taxation of international financial transactions, and

- introduction of solutions to counteract the existence of harmful tax regimes.

In connection with the OECD's action plan, the EU authorities undertook initiatives corresponding to individual areas. The EC's communication published on 
17 June 2015 states that EU directives should, where appropriate, be the preferred tool for implementing OECD proposals at the EU level to counter tax base erosion and profit shifting.

EU activities corresponding to the OECD Action Plan on BEPS include:

- Anti-tax-avoidance Directive (as a part of Anti-tax Avoidance Package);

- Council Directive (EU) 2015/2376 of 8 December 2015 amending Directive 2011/16/EU regarding the mandatory automatic exchange of information in the field of taxation;

-EC external strategy initiative to blacklist Third World countries based on lack of good tax governance principles, and

- EU Parent-Subsidiary Directive - GAAR.

To ensure the proper functioning of the internal market, it is necessary for Member States, at least, to comply with their obligations to counter tax base erosion and profit shifting and, to a wider extent, take measures to discourage tax avoidance practices and ensure fair and effective taxation in the Union in a sufficiently uniform and coordinated manner (Council Directive (EU) 2016/1164 of 12 July 2016 laying down rules against tax avoidance practices that directly affect the functioning of the internal market).

As for the examples of anti-tax avoidance solutions implemented or planned to be implemented in individual EU countries, horizontal monitoring in Austria can be mentioned. It is an innovative and progressively popular way of tax reporting in which the taxpayer signs a declaration obliging the company to disclose the files to the authorities. Both parties meet on a regular basis to discuss which tax practices are allowed and which are not, and after a few years, audits are no longer carried out. Although the start-up phase requires effort, the system provides a long-term benefit: both sides gain security and confidence, avoiding reluctance and related costs.

On the other hand, in Hungary, the new anti-hybrid rule in force from 2015 sets out the principle that any differences between the legal classification of legal relationships that are affected by international agreements cannot result in double non-taxation; if so, Hungary would take into account the relevant income in the tax base. Moreover, in the Czech Republic on 1 July 2017, the Czech Income Tax Act was amended to include the limitation of tax exemptions from dividends received by a Czech tax resident when dividends are received from the so-called "hybrid loans".

\section{Conclusions}

In the largest public debate on taxes and morals, and especially tax avoidance, in history, changes in international tax planning are inevitable. Greater control over international transactions carried out by tax authorities will certainly be a part of these changes. Many structures will no longer be allowed. Transparency will be the main focus for both taxpayers and collectors, and companies are expected to 
be subject to more stringent requirements to reveal where they have paid taxes and how much they have paid.

A large number of EU Member States, although not all members of the OECD itself, have committed to implementing BEPS activities, due to their participation in international forums and instruments relevant to the BEPS activities. In the EU, there is, therefore, a need to avoid different interpretations of BEEC OECD/G20 measures, taking into account the single market, which includes existing initiatives to increase tax efficiency and transparency. When implementing EU BEPS activities, a coordinated approach is crucial to avoid inconsistencies that could create uncertainty and administrative burdens. Jointly planned and agreed actions are the only way to prevent discrepancies generating new mismatches in the single market.

\section{References}

Anti-tax-avoidance directive. Briefing - EU Legislation in Progress. (2016). European Parliamentary Research Service.

Communication from the Commission to the European Parliament and the Council on tax transparency to fight tax evasion and avoidance $/ * \mathrm{COM} / 2015 / 0136$ final $\% /$.

Communication from the Commission to the European Parliament and the Council. An Action Plan to strengthen the fight against tax fraud and tax evasion $/ * \mathrm{COM} / 2012 / 722 \mathrm{final} * /$.

Council Directive (EU) 2016/1164 of 12 July 2016 laying down rules against tax avoidance practices that directly affect the functioning of the internal market, OJ L 193, 19.7.2016. Retrieved from http://eurlex.europe.eu/eli/dir/2016/1164/oj [access: 1.02.2019], pp. 1-14.

Gajewski, D.J. (2015). Międzynarodowe unikanie opodatkowania w Polsce - istota i przyczyny (ze szczególnym uwzględnieniem problematyki holdingów). In: D.J. Gajewski (red.), Międzynarodowe unikanie opodatkowania - wybrane zagadnienia. Warszawa: Krajowa Izba Gospodarcza.

HM Treasury, HM Revenue \& Customs (2015). Tackling tax evasion and avoidance. Retrieved from https:// assets.publishing.service.gov.uk/government/uploads/system/uploads/attachment_data/file/413931/ Tax_evasion_FINAL_with_covers_and_right_sig_.pdf\#page=9 [access: 1.02.2019].

Internal Revenue Service. (2012). Tax Year 2006 Tax Gap Estimate - Summary of Estimation Methods. Retrieved from https://www.irs.gov/pub/newsroom/summary_of_methods_tax_gap_2006.pdf [access: 1.02.2019].

Kurzac, M. (2017). Unikanie opodatkowania a uchylanie się od opodatkowania - o kryteriach rozróżniających. Studia Prawno-Ekonomiczne, 105, 11-22.

Laffer, A. (2004). The Laffer Curve: Past, Present, and Future. The Heritage Foundation.

Mosquera, V.I.J., Akunobera, F., Mazz, A., Quiñones Cruz, N., Schoueri, L.E., Roeleveld, J., West, C., Pistone, P., \& Zimmer, F. (2018). Tools used by developing countries to counteract aggressive tax planning in the light of transparency. Intertax, 46, 140-155. Retrieved from http://openaccess.leidenuniv.nl [access: 1.02.2019].

Murphy, R. (2012). Closing the European Tax Gap. A Report for the Group of the Progressive Alliance of Socialists \& Democrats in the European Parliament. Tax Research UK. Retrieved from http://www.socialistsanddemocrats.eu/gpes/media3/documents/3842_EN_richard_murphy_eu_tax_gap_en_120229. pdf [access: 1.02.2019].

OECD. (2007). International tax terms for the participants in the OECD programme of cooperation with non-OECD economies. Centre For Tax Policy and Administrations. Retrieved from http://www.oecd. org [access: 1.02.2019]. 
Pobrane z czasopisma Annales $\mathrm{H}$ - Oeconomia http://oeconomia.annales.umcs.pl

Data: 26/04/2023 12:04:16

THE PHENOMENON OF TAX AVOIDANCE - THE ESSENCE, CAUSES AND MEASURES...

OECD. (2013). Action Plan on Base Erosion and Profit Shifting. Retrieved from http://www.oecd.org [access: 1.02.2019].

Pasternak-Malicka, M. (2013). Przeciwdziałanie unikaniu i uchylaniu się od opodatkowania w UE. Humanities and Social Sciences, XVIII, 55-69.

Polish Tax Ordinance Act of 29 August 1997 (consolidated text, Journal of Laws 2018, item 800).

Smith, A. (1954). Badania nad natura i przyczynami bogactwa narodów, Vol. 2. Warszawa: PWN.

Swedish National Tax Agency. (2008). The Tax Gap Map for Sweden. Retrieved from https:/www.skatteverket.se/download/18.361dc8c15312eff6fd2b9a4/1473840293366/Report_2008_1B.pdf [access: 1.02.2019]. 